Article

\title{
Design, Synthesis, and Evaluation of Homochiral Peptides Containing Arginine and Histidine as Molecular Transporters
}

\author{
Naglaa Salem El-Sayed ${ }^{1,2}$, Taryn Miyake ${ }^{1}$, Amir Nasrolahi Shirazi ${ }^{1}$, Shang Eun Park ${ }^{1}$, \\ Jimmy Clark ${ }^{1}$, Stephani Buchholz ${ }^{1}$, Keykavous Parang ${ }^{1}$ (D) and Rakesh Tiwari ${ }^{1, *}$ \\ 1 Center for Targeted Drug Delivery, Department of Biomedical and Pharmaceutical Sciences, \\ Chapman University School of Pharmacy, Harry and Diane Rinker Health Science Campus, \\ Irvine, CA 92618, USA; nsibrahim18@gmail.com (N.S.E.-S.); miyak106@mail.chapman.edu (T.M.); \\ nasrolahishirazi@gmail.com (A.N.S.); park327@mail.chapman.edu (S.E.P.); \\ clark217@mail.chapman.edu (J.C.); buchh101@mail.chapman.edu (S.B.); \\ parang@chapman.edu (K.P.) \\ 2 Cellulose and Paper Department, National Research Center, Dokki, Cairo 12622, Egypt \\ * Correspondence: tiwari@chapman.edu; Tel.: +1-714-516-5483
}

Received: 3 May 2018; Accepted: 26 June 2018; Published: 29 June 2018

\begin{abstract}
Linear $(\mathrm{HR})_{\mathrm{n}}$ and cyclic $[\mathrm{HR}]_{\mathrm{n}}$ peptides $(\mathrm{n}=4,5)$ containing alternate arginine and histidine residues were synthesized. The peptides showed $0-15 \%$ cytotoxicity at $5-100 \mu \mathrm{M}$ in human ovarian adenocarcinoma (SK-OV-3) cells while they exhibited $0-12 \%$ toxicity in human leukemia cancer cell line (CCRF-CEM). Among all peptides, cyclic $[\mathrm{HR}]_{4}$ peptide was able to improve the delivery of a cell impermeable fluorescence-labeled phosphopeptide by two-fold. Fatty acids of different alkyl chain length were attached at the $N$-terminal of the linear peptide $(\mathrm{HR})_{4}$ to improve the molecular transporter property. Addition of fatty acyl chains was expected to help with the permeation of the peptides through the cell membrane. Thus, we synthesized seven fatty acyl derivatives of the linear $(\mathrm{HR})_{4}$ peptide. The peptides were synthesized using Fmoc/ $t$ Bu solid phase peptide chemistry, purified by reverse-phase high-performance liquid chromatography (RP-HPLC) and characterized by matrix-assisted laser desorption/ionization (MALDI) spectrometry. The fatty acyl peptides containing $\mathrm{C}_{8}, \mathrm{C}_{12}, \mathrm{C}_{14}$, and $\mathrm{C}_{18}$ alkyl chain did not show cytotoxicity on SK-OV-3 or CCRF-CEM cell lines up to $50 \mu \mathrm{M}$ concentration; however, at higher concentration $(100 \mu \mathrm{M})$, they showed mild cytotoxicity. For example, $\mathrm{C}_{16}-(\mathrm{HR})_{4}$ was also found to reduce the proliferation of SK-OV-3 cells by $11 \%$ at $50 \mu \mathrm{M}$ and $\mathrm{C}_{20}-(\mathrm{HR})_{4}$ showed mild toxicity at $10 \mu \mathrm{M}$, reducing the proliferation of SK-OV-3 cells by $21 \%$. Increase in the length of alkyl chain showed cytotoxicity to the cell lines. $\mathrm{C}_{20}-(\mathrm{HR})_{4}$ peptide showed better efficiency in translocation of $\mathrm{F}^{\prime}$-GpYEEI to SK-OV-3 than the phosphopeptide alone. Further investigation of $\mathrm{C}_{20}-(\mathrm{HR})_{4}$ peptide efficacy showed that the peptide could deliver doxorubicin and epirubicin into SK-OV-3 and also improved the drug antiproliferative ability. These studies provided insights into understanding the structural requirements for optimal cellular delivery of the fatty acyl-(HR) $)_{4}$ peptide conjugates.
\end{abstract}

Keywords: anticancer drugs; fatty acyl peptides; histidine; phosphopeptides; molecular transporters; cytotoxicity

\section{Introduction}

Cell-penetrating peptides (CPPs) also known as protein transduction domains (PTDs), are a group of short peptides with up to 25-30 amino acids that are capable of penetrating the cell membrane. CPPs are characterized by their high loading capacity, high transduction efficiency and rapid 
transduction rate [1,2]. Therefore, they are considered as good candidates for translocation of bioactive macromolecules, such as proteins, nucleic acids, peptides, inorganic particles and liposomes into cells [3-6].

CPPs are classified according to their physicochemical nature into amphipathic, hydrophobic or cationic peptides. Other classification is based on the origin of CPPs, dividing them into protein-derived CPPs, for example, TAT peptide and penetratin, model peptides as a MAP, KLAL, polyarginine, and finally designed peptides or chimeric peptides, which consist of functional domains of target proteins $[7,8]$.

CPPs differ from one to another in the routes of entry and intracellular transport mechanism for the therapeutic agents [9]. Two major routes for CPPs cellular internalization have been proposed: direct membrane translocation via pore-opening mechanism and endocytosis-mediated pathway, which divides into clathrin-dependent endocytosis, actin-dependent and caveolae-dependent micropinocytosis pathways [10]. The endosomal entrapment, potential cytotoxicity, immunogenicity and the lack of selectivity are the main obstacles that hinder the wide use of CPP's in the fields of imaging, drug delivery, and treatment [11].

Moreover, targeting the tumor tissue could be achieved through active targeting using specific tumor-associated biomarkers. However, active tumor triggering approaches have some difficulties because of the heterogeneity of the tumor tissues and the potential to develop resistance [12]. Therefore, the development of alternate generic targeting strategies using a global feature of various cancers, such as hypoxia [13], vasculature [14], or tumor acidic $\mathrm{pH}$ [15], are subjects of major interest. The diverse properties of naturally occurring amino acids permit their use for developing multifunctional CPPs that vary in their physicochemical properties including their degree of amphiphilicity, pKa, as well as their biological activities.

Among these amino acids, histidine (abbreviated as His or $\mathrm{H}$ ) is an essential amino acid with a protonable imidazolyl group, which is required for many enzymatic activities [16]. Furthermore, several reports emphasized the impact of incorporation of histidine amino acid into a peptide sequence that can be used for various applications. For example, Gaspar et al. reported the successful isolation and recovery of minicircle DNA biopharmaceuticals by using a histidine-based peptide of sequence $\left(\mathrm{C}_{2} \mathrm{H}_{6}\right)$ /zinc ions complex [16]. Liu et al. reported that histidine-containing nona arginine $\left(\mathrm{HR}_{9}\right)$ combined with semiconductor quantum dots (QDs) are efficient, non-toxic drug delivery systems [17]. Li et al. demonstrated that co-grafting of arginine and histidine amino acids onto the poly( $\omega$-aminohexyl methacrylamide) (PAHMAA) polymer improved the polymer serum-compatibility, gene transfection efficacy and decreased its cytotoxicity [18]. Replacement of all basic amino acids in the antimicrobial peptide ARK24 and AKK24 by histidines yielded the histidine-rich peptides AHH24:1 and AHH24:2, respectively and the addition of $\mathrm{Zn}^{2+}$ restored the antimicrobial activity of the AHH peptides. Bacalum et al. reported that the substitution of tryptophan by histidine in the antimicrobial peptide sequence $\mathrm{R}_{2} \mathrm{~W}_{2} \mathrm{RW}_{2} \mathrm{R}_{2}$ modulated the antimicrobial activity [19].

In our previous studies, we explored the combination of attaching different hydrophobic amino acids and charged residues with or without fatty acids to get homochiral CPPs as molecular transporters named $[W R]_{4}$ and $[W R]_{5}[2,20-24]$. Also, a further effort led to the development of new series of peptides named $[C R]_{4}$ and $[C R]_{5}$ which contains cysteine and arginine residues that showed an efficient molecular transporter's property for a diverse group of bioactive molecules [25]. In the frame work of developing unique CPPs to explore their application of molecular transporter properties and the targeting of cargos to cancer cells, we aimed to develop novel CPPs with alternating arginine and histidine amino acids to evaluate their ability to translocate various biomolecular cargoes of different molecular size and hydrophobic nature to the cancer cells. We hypothesized that the hydrophilic positively-charged side chain of arginine could interact with the negatively-charged phospholipid of the cell membrane. Moreover, the hydrophilic nature and $\mathrm{pKa}$ value of histidine imidazolyl ring ( 6.0) could affect the transport of the cargos based on $\mathrm{pH}$ of cancerous cells [26]. Also, the impact of attaching fatty acid on modulating the activity and cytotoxicity of $[\mathrm{HR}]_{4}$ peptides was investigated. 
The cytotoxicity and transporting ability for many bioactive molecules by the synthesized peptides were studied at different peptides concentrations.

\section{Result and Discussion}

\subsection{Chemistry}

\subsubsection{Synthesis of Linear and Cyclic Peptides}

Four homochiral amphipathic peptides of sequence linear $(\mathrm{HR})_{4}$, linear $(\mathrm{HR})_{5}$, cyclic $[\mathrm{HR}]_{4}$ and cyclic $[H R]_{5}$ were synthesized by standard Fmoc solid-phase peptide synthesis (SPPS) on 2-chlorotrityl resin as solid support. Parentheses' ( ) represent linear (l) peptide where as square brackets' [ ] represent cyclic [c] peptide. All peptides were purified by preparative RP-HPLC and analyzed by MALDI-TOF/TOF mass spectroscopy (see Supplementary Materials). Scheme 1 depicts the synthesis of the peptides. The protected amino acids were assembled on $\mathrm{H}$-Arg(Pbf)-2-chlorotrityl resin. Cleavage of the resin in the presence of DCM:TFE:AcOH followed by cyclization generated cyclic peptides [HR $]_{4}$ and $[\mathrm{HR}]_{5}$. Complete deprotection of the resin and the protecting groups in the presence of reagent $\mathrm{R}$ (trifluoroacetic acid (TFA)/thioanisole/anisole/1,2-ethanedithiol (EDT) (90:5:2:3, $v / v / v / v$ ) afforded linear peptides $1(\mathrm{HR})_{4}$ and $1(\mathrm{HR})_{5}$.

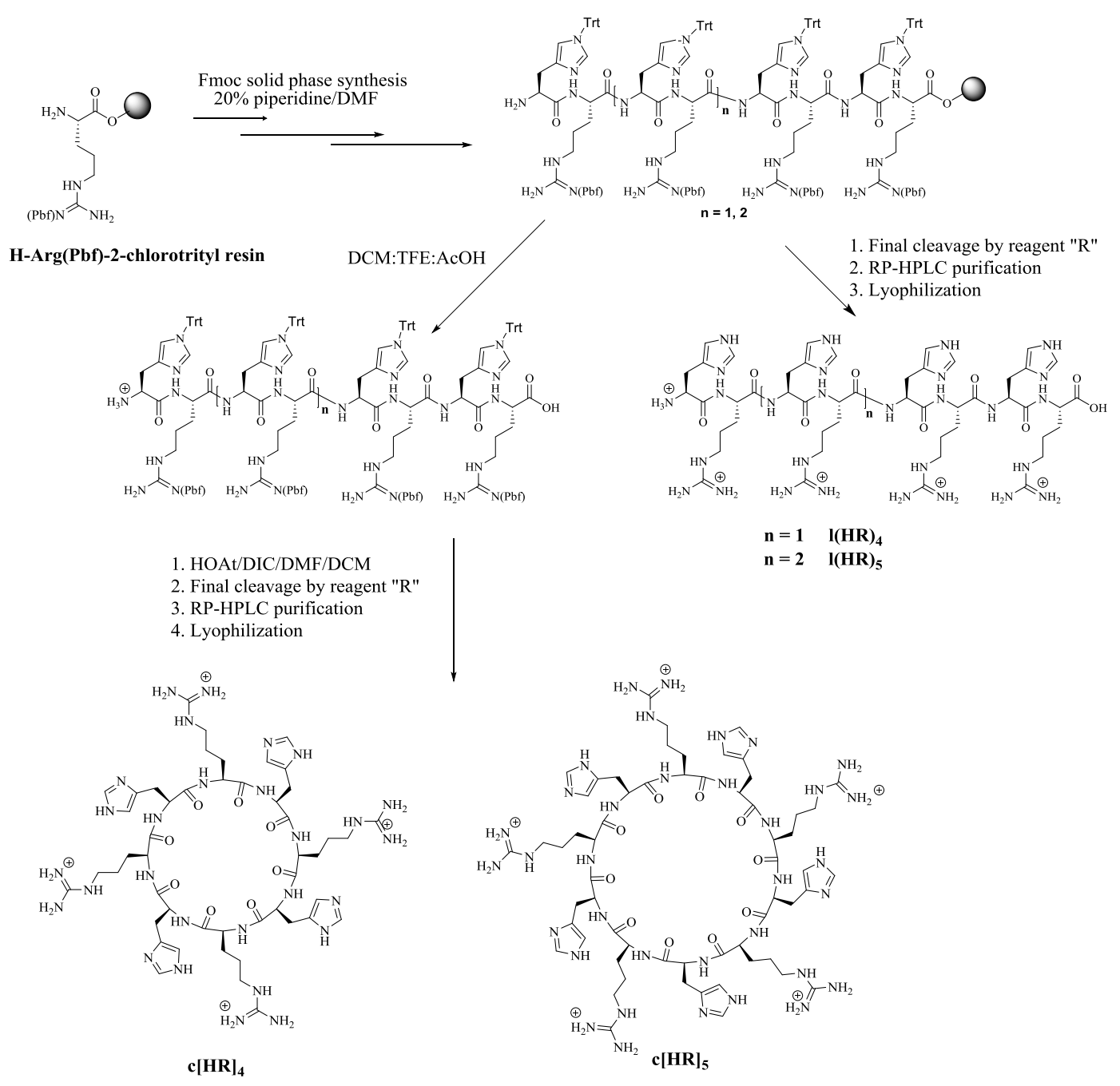

Scheme 1. Synthesis of $1(\mathrm{HR})_{4}, 1(\mathrm{HR})_{5}, \mathrm{c}[\mathrm{HR}]_{4}$, and $\mathrm{c}[\mathrm{HR}]_{5}$. 


\subsubsection{Synthesis of Fatty Acyl Linear $(\mathrm{HR})_{4}$ Peptides}

It was expected that the attachment of fatty acids or hydrophobic residues to a cationic CPPs will increase the peptide's hydrophobicity. Hydrophobicity enhances the interactions with the cell membrane phospholipids leading to increased cellular uptake, and/or modulating both activity and selectivity [25,27-29]. Thus, a library of fatty acyl-(HR $)_{4}$ peptides were synthesized using Wang resin as the solid support as shown in Scheme 2. After peptide assembly on the solid-phase resin, the peptide underwent reaction with a fatty acyl anhydride or other selected fatty acid namely suberic acid $\left(\mathrm{C}_{8}\right)$, lauric acid $\left(C_{12}\right)$, myristic acid $\left(C_{14}\right)$, palmitic acid $\left(C_{16}\right)$, oleic acid $\left(C_{18}\right)$, and arachidic acid $\left(C_{20}\right)$ using HBTU as activating agent and DIPEA as a base. $\mathrm{C}_{20}-(\mathrm{HR})_{2}, \mathrm{C}_{20}-(\mathrm{HR})_{3}$, and $\mathrm{C}_{20}-(\mathrm{HR})_{5}$, (Figure 1) were also synthesized using a similar procedure to correlate the peptide cellular transporter activities with the number of amino acids residues.

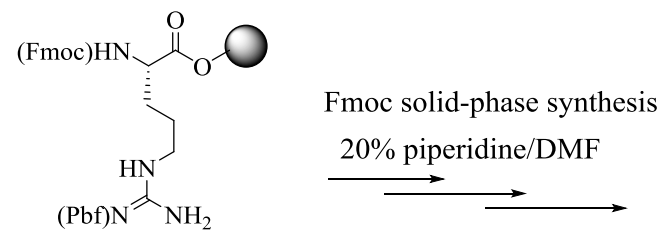

Fmoc-Arg(Pbf)-Wang resin

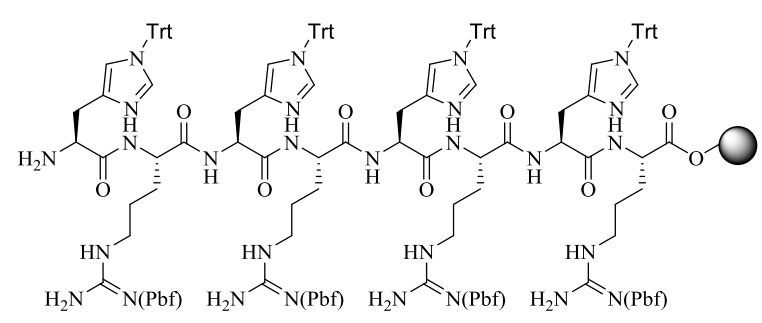

(i) Fatty acyl anhydride or RCOOH/ DIPEA/ HBTU/ DMF

(ii) TFA/thioanisole/anisole/EDT

(iii) RP-HPLC purification

(iv) lyophlizaton

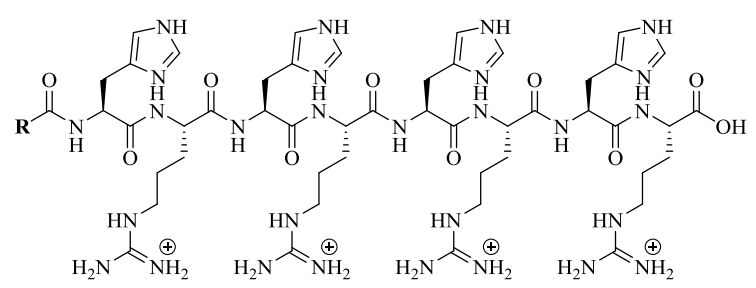

Fatty acyl - (HR)

\begin{tabular}{|l|l|l|}
\hline Fatty acid & $\mathrm{R}$ & Abbreviation \\
\hline Acetic anhydride & $\mathrm{CH}_{3}$ & $\mathrm{C}_{2}$ \\
\hline Suberic acid & ${ }^{\mathrm{COOH}\left(\mathrm{CH}_{2}\right)_{5} \mathrm{CH}_{2}-}$ & $\mathrm{C}_{8}$ \\
\hline Lauric acid & $\mathrm{CH}_{3}\left(\mathrm{CH}_{2}\right)_{10^{-}}$ & $\mathrm{C}_{12}$ \\
\hline Myristic acid & $\mathrm{CH}_{3}\left(\mathrm{CH}_{2}\right)_{12^{-}}$ & $\mathrm{C}_{14}$ \\
\hline Palmitic acid & $\mathrm{CH}_{3}\left(\mathrm{CH}_{2}\right)_{14^{-}}$ & $\mathrm{C}_{16}$ \\
\hline Oleic acid & $\mathrm{CH}_{3}\left(\mathrm{CH}_{2}\right)_{7} \mathrm{CH}=\mathrm{CH}\left(\mathrm{CH}_{2}\right)_{6} \mathrm{CH}_{2-}-$ & $\mathrm{C}_{18}$ \\
\hline Arachedic acid & $\mathrm{CH}_{3}\left(\mathrm{CH}_{2}\right)_{18} \mathrm{CH}_{2-}$ & $\mathrm{C}_{20}$ \\
\hline
\end{tabular}

Scheme 2. Synthesis of fatty acyl conjugates of linear $(\mathrm{HR})_{4}$ peptides.<smiles>CCCCC(=O)NC(Cc1c[nH]cn1)C(=O)N[C@@H](CCCNC(=N)N)C(=O)NC(Cc1c[nH]cn1)C(=O)N[C@@H](CCCNC(=N)N)C(=O)O</smiles>

$\mathrm{C}_{20}$-(HR)<smiles>CCCCCCCCNC(=O)NC(Cc1c[nH]cn1)C(=O)N[C@@H](CCCNC(=N)N)C(=O)NC(Cc1c[nH]cn1)C(=O)N[C@@H](CCCNC(=N)N)C(=O)NC(Cc1c[nH]cn1)C(=O)N[C@@H](CCCNC(=N)N)C(=O)O</smiles>

$\mathrm{n}=1 ; \mathrm{C}_{20}-(\mathrm{HR})_{3}$ $\mathrm{n}=3 ; \mathrm{C}_{20}-(\mathrm{HR})_{5}$

Figure 1. Chemical structures of $\mathrm{C}_{20}-(\mathrm{HR})_{2}, \mathrm{C}_{20}-(\mathrm{HR})_{3}$, and $\mathrm{C}_{20}-(\mathrm{HR})_{5}$. 


\subsection{Cell Assay}

\subsubsection{Peptide Cytotoxicity}

The cytotoxicity of $1(\mathrm{HR})_{4}, 1(\mathrm{HR})_{5}, \mathrm{c}[\mathrm{HR}]_{4}$, and $\mathrm{c}[\mathrm{HR}]_{5}$ was evaluated in human ovarian (SK-OV-3) and leukemia (CCRF-CEM) cancer cells at different peptides concentrations $(5,10,25,50$, and $100 \mu \mathrm{M})$ after incubation for $24 \mathrm{~h}$ (Figure 2). The peptide solutions had a final concentration of $1 \%$ DMSO in the assay. The peptides showed 5-10\% toxicity at 5-100 $\mu \mathrm{M}$ peptide concentration in SK-OV-3 and $0-13 \%$ in CCRF-CEM at the same concentrations as compared to negative control (1\% DMSO). From the cytotoxicity studies, it is clear that no significant difference was observed in the peptides cytotoxicity between linear and cyclic arginine/histidine-containing peptides and the number of amino acids did not demonstrate a detectable difference in the toxicity profile of the four peptides at all the investigated concentrations.

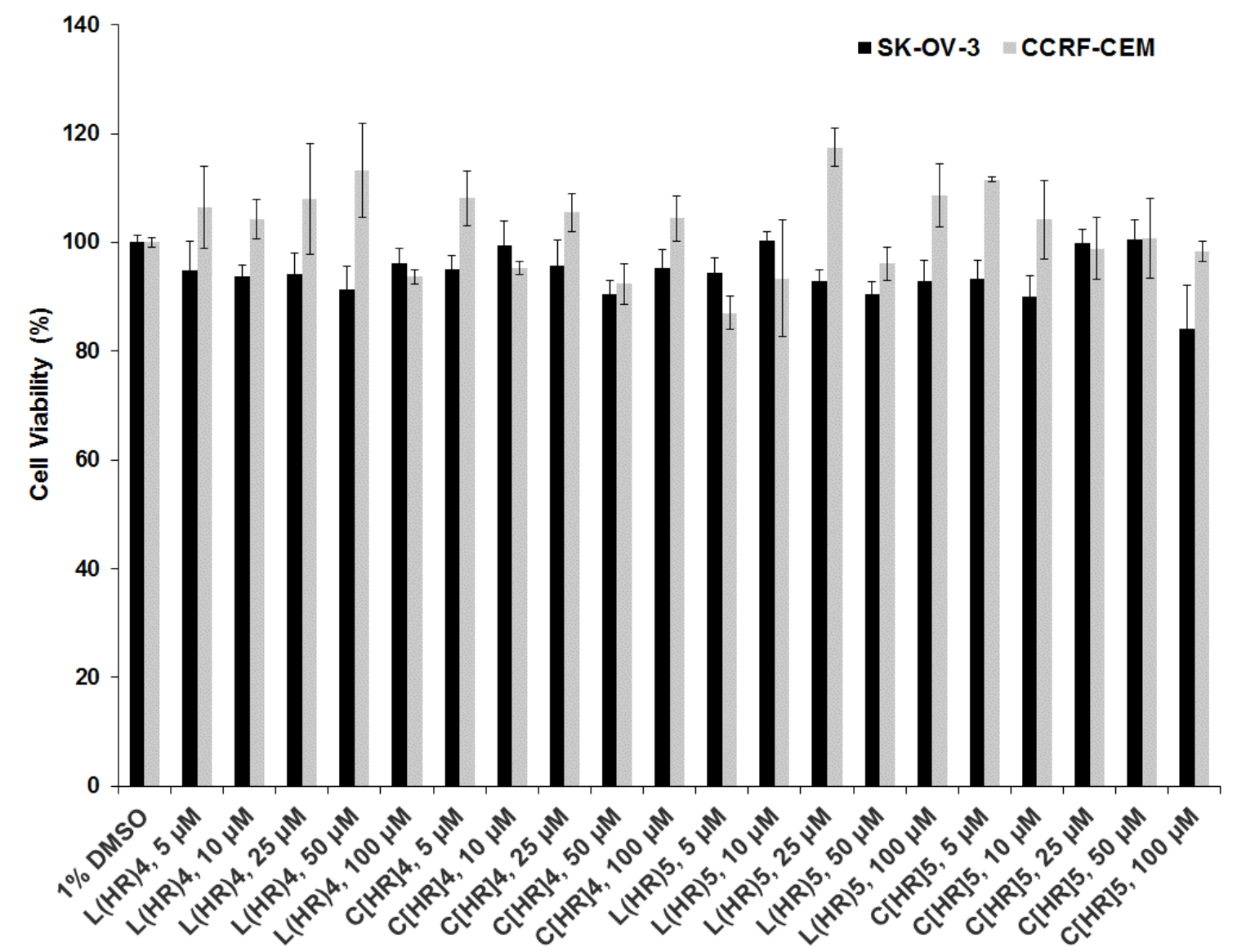

Figure 2. Cytotoxicity study for $1(\mathrm{HR})_{4}, 1(\mathrm{HR})_{5}, \mathrm{c}[\mathrm{HR}]_{4}$, and $c[\mathrm{HR}]_{5}$ at 5, 10, 25, 50, and $100 \mu \mathrm{M}$ in SK-OV-3 and CCRF-CEM cell lines after $24 \mathrm{~h}$ incubation.

However, the change in the cytotoxicity profile was observed upon the attachment of fatty acids of different chain length and degree of hydrophobicity to $1(\mathrm{HR})_{4}$ peptide. $1(\mathrm{HR})_{4}$ conjugated with acetyl $\left(C_{2}\right)$, suberic $\left(C_{8}\right)$, lauroyl $\left(C_{12}\right)$, myristoyl $\left(C_{14}\right)$, and oleoyl $\left(C_{18}\right)$ fatty acids substituent showed $0-2 \%$ cytotoxicity on CCRF-CEM and $0 \%$ on SK-OV-3 at 10 and $50 \mu \mathrm{M}$ peptide concentration as compared to negative (1\% DMSO) and positive (Doxorubicin (Dox, $10 \mu \mathrm{M})$ ) control. Increasing the concentration to $100 \mu \mathrm{M}$, caused a reduction in the cell viability for $1(\mathrm{HR})_{4}$ conjugated with $\mathrm{C}_{2}$ by $16 \%, \mathrm{C}_{8}$ by $15 \%$, $\mathrm{C}_{12}$ by $0 \%, \mathrm{C}_{14}$ by $18 \%$, and $\mathrm{C}_{18}$ by $27 \%$, respectively in SK-OV-3. The viability in CCRF-CEM cell line was reduced by $27-60 \%$ when the cells were treated with peptides at $100 \mu \mathrm{M}$. Although the palmitoyl conjugate, $\mathrm{C}_{16}-(\mathrm{HR})_{4}$, had $0 \%$ cytotoxic effect on both the cell lines at $10 \mu \mathrm{M}$ and the cell viability was 
reduced by $35-70 \%$ at peptide concentrations of 50 and $100 \mu \mathrm{M}$, respectively. The arachidyl peptide conjugate, $\mathrm{C}_{20}-(\mathrm{HR})_{4}$, was toxic at all concentrations, where the cell viability was significantly reduced by (45-66\%) in CCRF-CEM cells and by (31-80\%) in SK-OV-3 cells, as illustrated in (Figure 3). Cancer cells proliferate and produce lactic acid and result in acidic $\mathrm{pH}(\sim 6.5)$. We assume that the observed cytotoxicity of peptide was due to an increase of hydrophobicity of the fatty acyl peptide $\left(\mathrm{C}_{20}-(\mathrm{HR})_{4}\right)$ and cellular permeability as compared to $(\mathrm{HR})_{4}$ peptide. The $\mathrm{pH}$ of the media for both cancer cell lines after $72 \mathrm{~h}$ of treatment for $1(\mathrm{HR})_{4}$ peptide was found to be acidic $(\mathrm{pH} \sim 6.5)$ in comparison to the weak basic $\mathrm{pH}(\sim 7.5)$ for $\mathrm{C}_{20}-(\mathrm{HR})_{4}$ treated cells. The untreated control cells were found to have a pH of 6.5 , showing $100 \%$ proliferation in the cancer cells. $(\mathrm{HR})_{4}$ is protonated at an acidic $\mathrm{pH}$ of the medium that results in membrane ionic interactions that did not improve permeability due to the lack of hydrophobicity to interact with the lipid residues in the membrane. On the other hand, fatty acyl compounds, such as $\mathrm{C}_{16^{-}}(\mathrm{HR})_{4}$ and $\mathrm{C}_{20}-(\mathrm{HR})_{4}$ analogs, resulted in the cytotoxicity. The $\mathrm{pH}$ of cellular media was found to be $\sim 7.5$ for these compounds. At this $\mathrm{pH}$, the majority of histidine residues are more deprotonated and the compound is more hydrophobic. Furthermore, $\mathrm{C}_{20}$ acyl chain contributes to increased hydrophobicity, and more cellular permeability occurs due to the enhanced hydrophobicity. The enhanced hydrophobicity at higher $\mathrm{pH}$ is due to a higher ratio of deprotonation in histidine residues in the series of fatty acyl-(HR $)_{4}$ peptides that lead to enhanced cellular permeability. Thus, a small difference in $\mathrm{pH}(6.5-7.5)$ has a significant effect on the proliferation of cancer cells. Therefore, fatty acylation significantly changed the property of $1(\mathrm{HR})_{4}$ peptides.

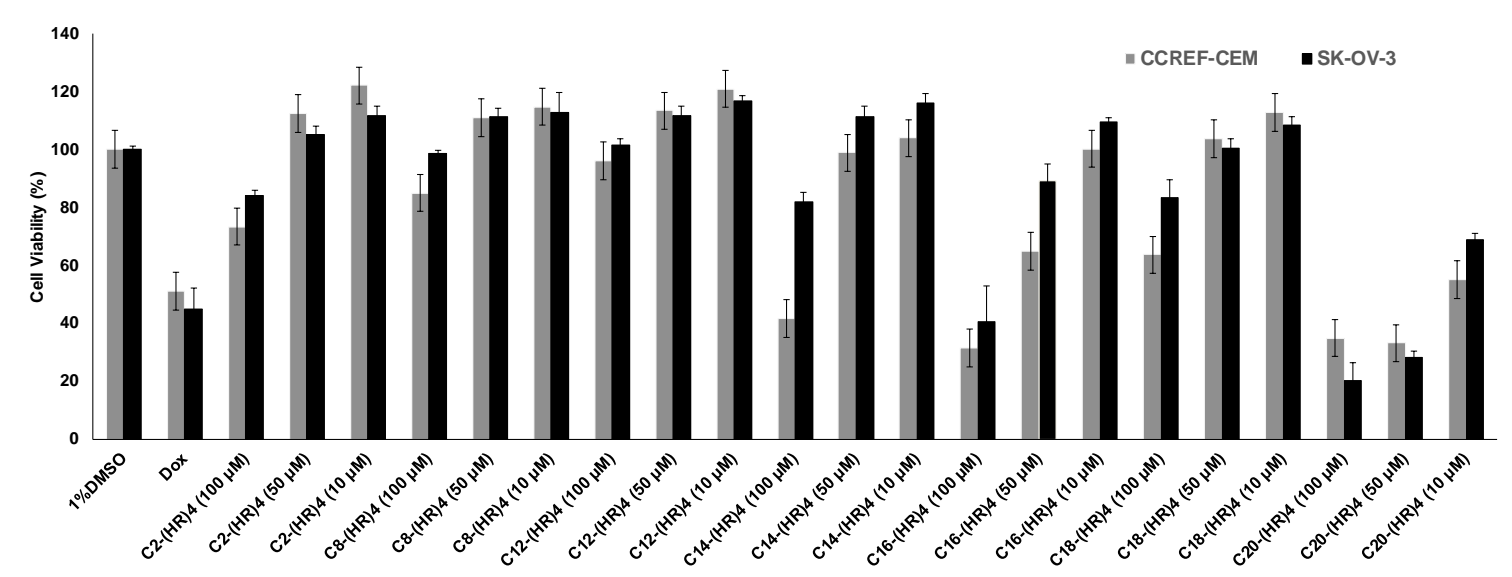

Figure 3. Cytotoxicity study for the fatty acyl-(HR $)_{4}$ derivatives at concentrations of 10,50 and $100 \mu \mathrm{M}$ after $72 \mathrm{~h}$ incubation with CCRF-CEM and SK-OV-3 cells.

\subsubsection{Molecular Transporting Efficiency of the Peptides}

The synthesized conjugated peptides were evaluated for their ability to mediate the cellular internalization for fluorescence-labeled phosphopeptide containing the sequence $\mathrm{F}^{\prime}$-GpYEEI (where $\mathrm{F}^{\prime}$ represents carboxyfluorescein and $\mathrm{pY}$ represents phosphotyrosine amino acid). Phosphopeptides are considered as reagent probes that mimic phosphoproteins involved in signal transduction. They are usually employed in studying the mechanism of phosphoprotein-protein, protein-ligand interactions, the determination of phosphatases enzyme's specificity to substrates, and the identification of phosphotyrosine receptors binding domains (PTB) [21,30]. The presence of negatively-charged phosphate groups in addition to the hydrophobic nature of phosphopeptides limited their ability to bypass the cell membrane and reduce their cellular uptake. Consequently, several approaches have been suggested to promote their transportation through the cell membrane into the cell cytoplasm $[21,26]$.

Fluorescently labeled phosphopeptide $\mathrm{F}^{\prime}$-GPYEEI at a concentration of $5 \mu \mathrm{M}$ was incubated with the linear and cyclic peptides $\left(\mathrm{l}(\mathrm{HR})_{4}, 1(\mathrm{HR})_{5}, \mathrm{c}[\mathrm{HR}]_{4}\right.$, and $\left.\mathrm{c}[\mathrm{HR}]_{5}\right)$ at a concentration of $50 \mu \mathrm{M}$ for $2 \mathrm{~h}$. The cellular internalization for $\mathrm{F}^{\prime}$-GpYEEI by c $[\mathrm{HR}]_{5}, 1(\mathrm{HR})_{4}$, and $\mathrm{l}(\mathrm{HR})_{5}$ did not differ significantly 
from that of the phosphopeptide alone. However, the cellular uptake of $\mathrm{F}^{\prime}$-GpYEEI was increased by two folds when loaded with $\mathrm{c}[\mathrm{HR}]_{4}$. These data indicate that only cyclic $[\mathrm{HR}]_{4}$ was able to promote the delivery of $F^{\prime}$-GPYEEI (Figure 4).

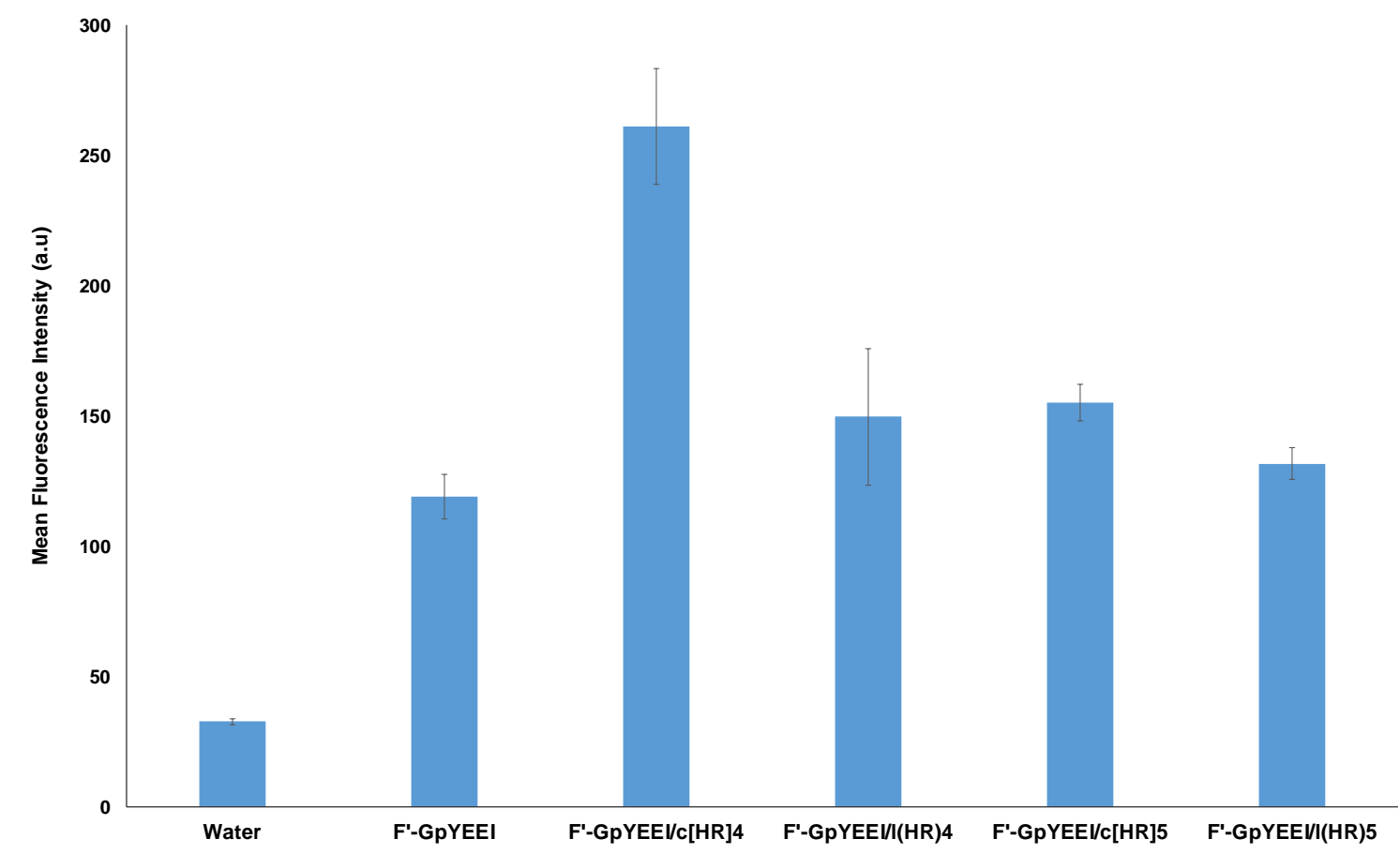

Figure 4. Cellular uptake study of $\mathrm{F}^{\prime}$-GpYEEI phosphopeptide at $5 \mu \mathrm{M}$ by c[HR $]_{4}, \mathrm{c}[\mathrm{HR}]_{5}, 1(\mathrm{HR})_{4}$, and $\mathrm{l}(\mathrm{HR})_{5}$ at $50 \mu \mathrm{M}$ peptide concentration in SK-OV-3 cancer cell lines.

The four alternate $\mathrm{H}$ and $\mathrm{R}$ residues showed ability in delivering phosphopeptide ( $\mathrm{F}^{\prime}$-GPYEEI) inside the SK-OV-3 cells. Therefore, we investigated the impact of attachment of fatty acyl chain with different hydrophobic alkyl chains to $1(\mathrm{HR})_{4}$ in modulating the cellular uptake using fatty acylation strategy [27]. The conjugation of fatty acyl chain to $1(\mathrm{HR})_{4}$ peptide affected the molecular transportation ability of $\mathrm{F}^{\prime}$-GpYEEI peptide. When $\mathrm{F}^{\prime}$-GPYEEI was incubated with the fatty acyl-(HR $)_{4}$ peptides at a concentration of $50 \mu \mathrm{M}$ for $2 \mathrm{~h}$, it was found that $\mathrm{C}_{16}-(\mathrm{HR})_{4}$ and $\mathrm{C}_{20}-(\mathrm{HR})_{4}$ were the most effective in promoting the cellular uptake. They improved the cellular uptake of $\mathrm{F}^{\prime}$-GPYEEI by 1.5 and 2.0 folds, respectively, as compared to the free form of $\mathrm{F}^{\prime}$-GpYEEI. Fatty acyl $(\mathrm{HR})_{4}$ peptides containing acetyl or suberoyl moieties increased the uptake of $\mathrm{F}^{\prime}$-GpYEEI by $10 \%$, while $(\mathrm{HR})_{4}$ peptides with the lauroyl, myristoyl, and oleoyl moieties slightly reduced the uptake of $\mathrm{F}^{\prime}$-GPYEEI (Figure 5). Furthermore, the cellular uptake of $\mathrm{F}^{\prime}$-GpYEEI mediated by $\mathrm{C}_{20}-(\mathrm{HR})_{4}$ proved to be a concentration-dependent. For example, $\mathrm{C}_{20}-(\mathrm{HR})_{4}$ increased the uptake of $\mathrm{F}^{\prime}$-GpYEEI by about a factor of two at $5 \mu \mathrm{M}$ and increased by a factor of 2.5 at concentration $10 \mu \mathrm{M}$ as shown in (Figure 6). 


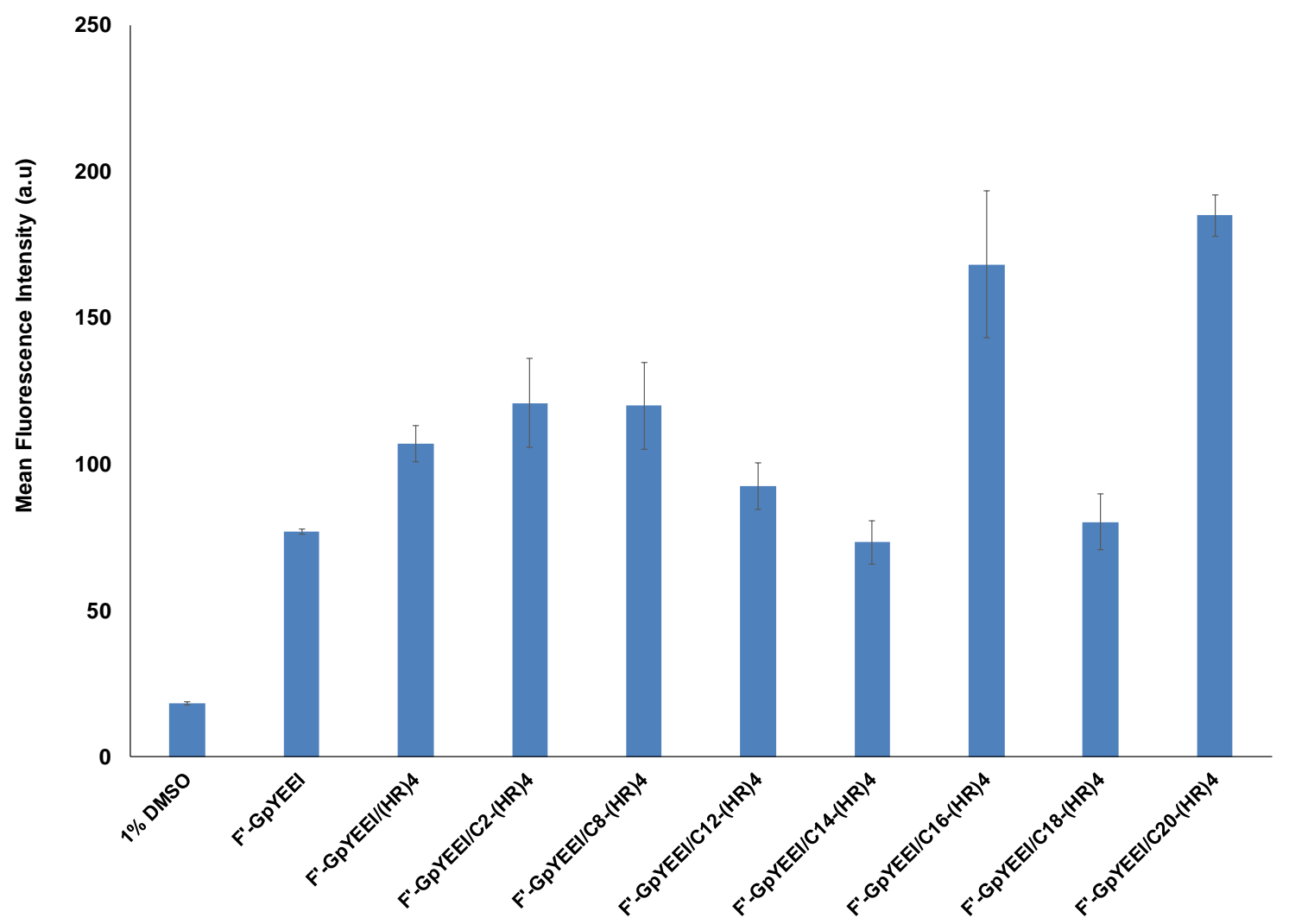

Figure 5. Cellular uptake study of $\mathrm{F}^{\prime}$-GPYEEI $(5 \mu \mathrm{M})$ by fatty acyl-(HR $)_{4}$ derivatives at $50 \mu \mathrm{M}$ in SK-OV-3 cancer cell lines.

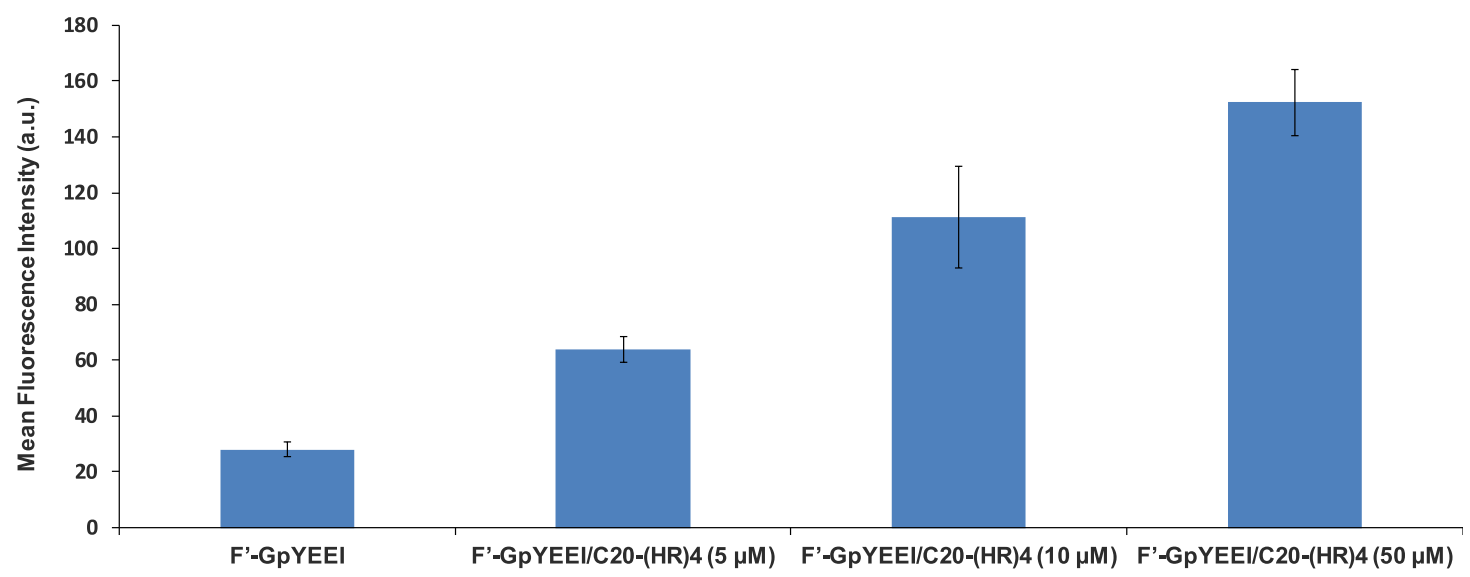

Figure 6. Cellular uptake studies $\mathrm{F}^{\prime}$-GpYEEI $(5 \mu \mathrm{M})$ in the presence of $\mathrm{C}_{20}-(\mathrm{HR})_{4}$ in SK-OV-3 cell lines at a concentration of 5,10 and $50 \mu \mathrm{M}$ of $\mathrm{C}_{20}-(\mathrm{HR})_{4}$.

Then we compared the cellular uptake of $\mathrm{F}^{\prime}$-GpYEEI with $\mathrm{C}_{20}-(\mathrm{HR})_{4}, 1(\mathrm{HR})_{4}$, and c $[\mathrm{HR}]_{4}$ at $50 \mu \mathrm{M}$ in the SK-OV-3 cells. Figure 7 showed that the $\mathrm{C}_{20}-(\mathrm{HR})_{4}$ was found to be the most effective in mediating the cellular uptake of $\mathrm{F}^{\prime}$-GpYEEI after $4 \mathrm{~h}$ by more than five folds as compared to $\sim 2$ folds by the $\mathrm{c}[\mathrm{HR}]_{4}$ in the SK-OV-3 cells. 


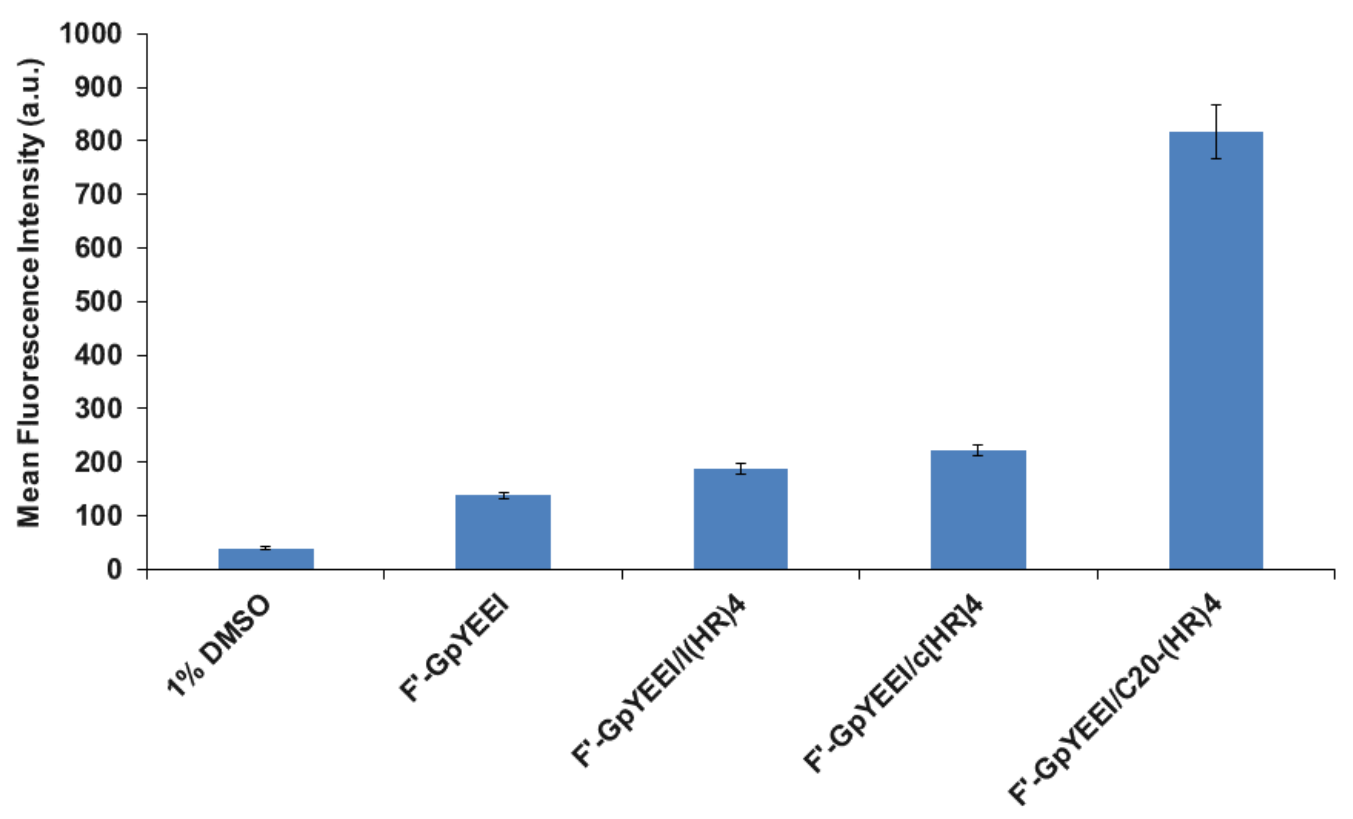

Figure 7. Comparative study for the cellular uptake of $\mathrm{F}^{\prime}$-GpYEEI $(5 \mu \mathrm{M})$ by $1(\mathrm{HR})_{4}, \mathrm{c}[\mathrm{HR}]_{4}$, and $\mathrm{C}_{20}-(\mathrm{HR})_{4}$ at $50 \mu \mathrm{M}$ in SK-OV-3 cell line.

Additionally, the effect of the number of amino acids on the transporting efficacy of $\mathrm{C}_{20}-(\mathrm{HR})_{\mathrm{n}}$ peptides was studied using CCRF-CEM cell line. Increasing the number of histidine and arginine amino acids $(n=2-5)$, increased the potentiality of $C_{20}-(H R)_{n}$ peptides in translocating $F^{\prime}$-GPYEEI into the CCRF-CEM cells after $3 \mathrm{~h}$. The $\mathrm{C}_{20}-(\mathrm{HR})_{2}$ peptide did not mediate the cellular uptake of $\mathrm{F}^{\prime}$-GpYEEI. $\mathrm{C}_{20}-(\mathrm{HR})_{5}$ peptide increased the cellular uptake by more than 10 times. Meanwhile, both $\mathrm{C}_{20}-(\mathrm{HR})_{4}$ and $\mathrm{C}_{20}-(\mathrm{HR})_{3}$ peptides displayed the same ability in translocating $\mathrm{F}^{\prime}$-GPYEEI into the CCRF-CEM cells. Both $\mathrm{C}_{20}-(\mathrm{HR})_{4}$ and $\mathrm{C}_{20}-(\mathrm{HR})_{3}$ fatty acyl peptides increased the cellular uptake of phosphopeptide by about 4.8 and 4.5 times respectively as compared to the free $\mathrm{F}^{\prime}$-GpYEEI (Figure 8 ).

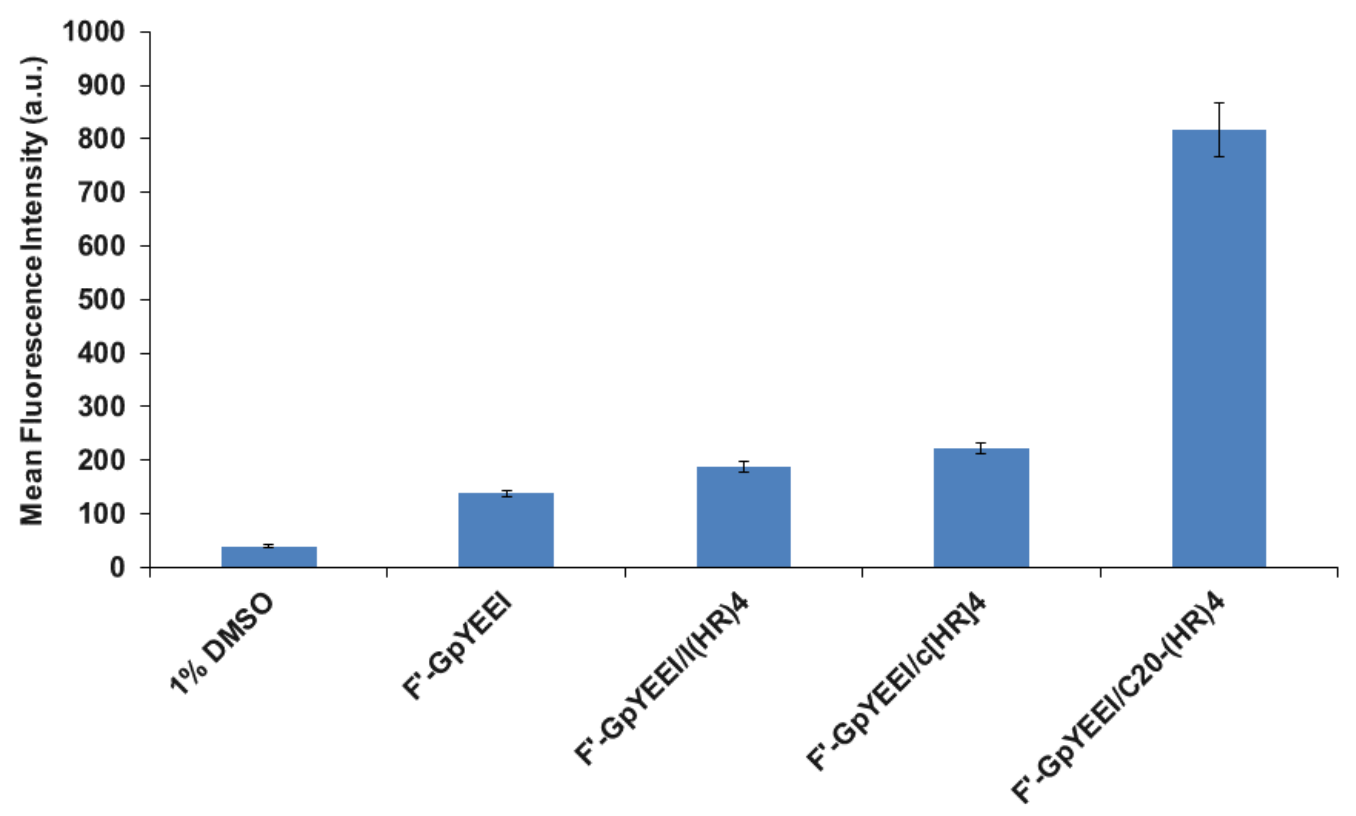

Figure 8. The cellular uptake of $\mathrm{F}^{\prime}$-GpYEEI at $5 \mu \mathrm{M}$ concentration by $\mathrm{C}_{20}-(\mathrm{HR})_{\mathrm{n}}$ peptides at $50 \mu \mathrm{M}$ peptide concentration in CCRF-CEM cell line. 


\subsubsection{Anticancer Drug Delivery Using $\mathrm{C}_{20}-(\mathrm{HR})_{4}$}

The efficiency of $\mathrm{C}_{20}-(\mathrm{HR})_{4}$ as drug carrier was evaluated by incubating the peptide at $50 \mu \mathrm{M}$ concentration with different anticancer drugs including (doxorubicin, etoposide, cisplatin, epirubicin, paclitaxel, and gemcitabine) at a drug concentration of $5 \mu \mathrm{M}$ for $72 \mathrm{~h}$, as shown in the (Figure 9). The anti-proliferation potency of doxorubicin and epirubicin significantly improved by two fold upon their loading with $\mathrm{C}_{20}-(\mathrm{HR})_{4}$. The physical mixture of paclitaxel or gemcitabine with $\mathrm{C}_{20}-(\mathrm{HR})_{4}$ peptide increased the drug toxicity only by 1.5 fold. On the other hand, $\mathrm{C}_{20}-(\mathrm{HR})_{4}$ did not improve the anti-proliferating potency of etoposide and paclitaxel in CCRF-CEM cell line but the cell viability in SK-OV-3 cell line was reduced by almost one and half fold as compared to the parent analogs.

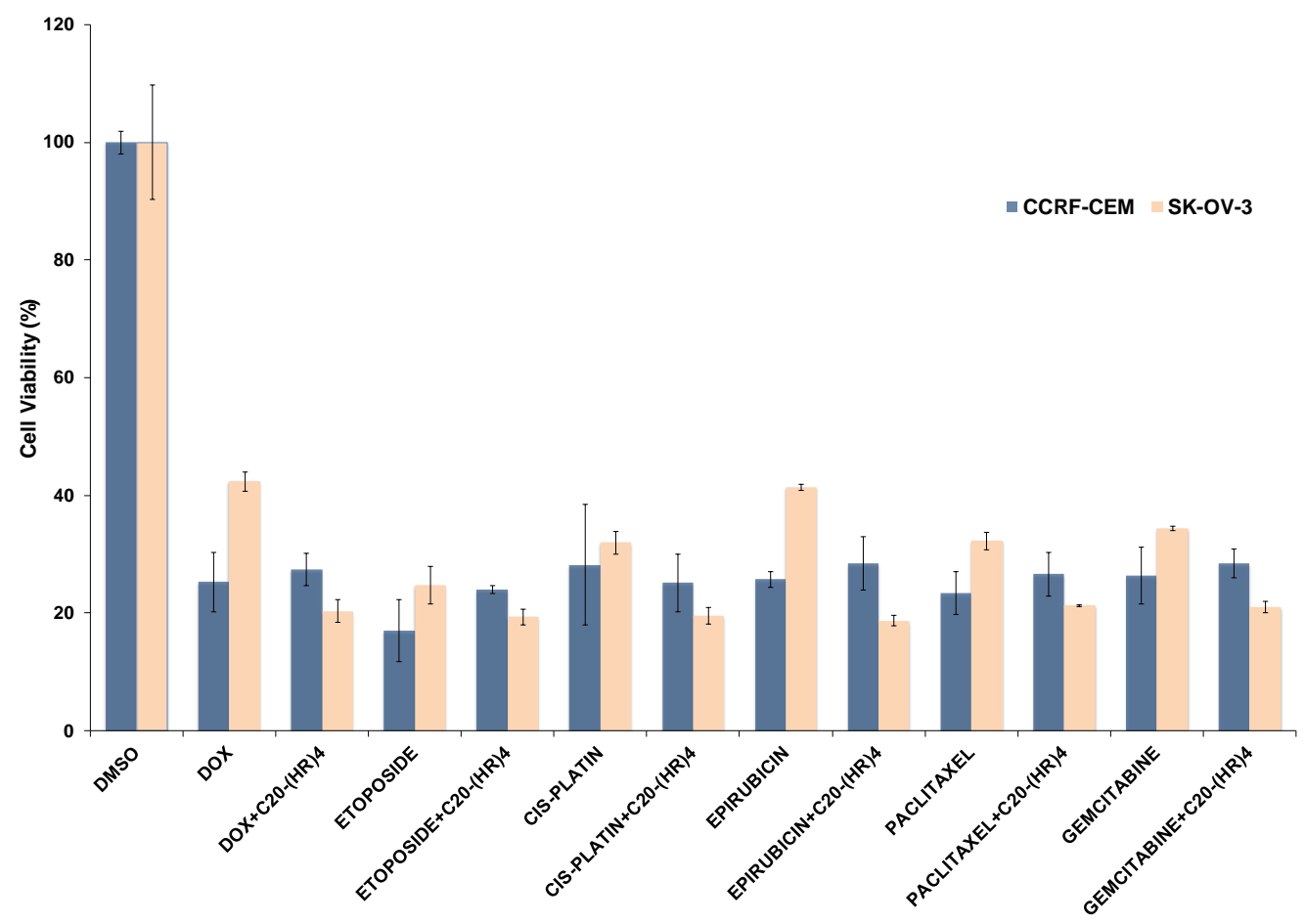

Figure 9. Anti-proliferative assay results for $\mathrm{C}_{20}-(\mathrm{HR})_{4}$ with different anticancer drugs.

\section{Materials and Methods}

\subsection{General Information}

All amino acids were purchased from Chem-Impex International, Inc. All other chemicals and reagents were purchased from Sigma-Aldrich Chemical Co. (Milwaukee, WI, USA). The chemical structures of final products were confirmed by high-resolution MALDI ABX SCIEX TOF/TOF 5800 at the University of California, Irvine, mass spectroscopy facility. The reactions for peptide synthesis were carried out in Bio-Rad polypropylene columns by shaking and mixing under nitrogen using a Glass-Col small tube rotator at room temperature according to our previously reported procedure [20-23]. The peptides were synthesized by solid-phase synthesis using $N$-(9-fluorenyl)-methoxycarbonyl (Fmoc)-based chemistry and employing Fmoc-L-amino acid building blocks. Linear peptides, $(\mathrm{HR})_{4}$, $(\mathrm{HR})_{5}$ and cyclic peptides, $[\mathrm{HR}]_{4}$ and $[\mathrm{HR}]_{5}$, were synthesized by solid-phase synthesis using $\mathrm{NH}_{2}$ - $\mathrm{Arg}$ (Pbf)-2-chlorotrityl resin. 2-(1H-Benzotriazole-1-yl)-1,1,3,3-tetramethyluronium hexafluoro phosphate (HBTU) and $\mathrm{N}, \mathrm{N}$-diisopropylethylamine (DIPEA) in $\mathrm{N}, \mathrm{N}$-dimethylformamide (DMF) were used as coupling and activating reagents, respectively. Fmoc deprotection at each step was carried out using piperidine in $\operatorname{DMF}(20 \% v / v)$. For the peptide synthesis, as representative examples, the synthesis of linear $(\mathrm{HR})_{4}$, cyclic $[\mathrm{HR}]_{4}$ and fatty acyl lauryl-(HR $)_{4}$ derivatives are described below. 


\subsubsection{Synthesis of Linear $(\mathrm{HR})_{4}$}

The linear peptide containing eight amino acids of alternative histidine and arginine residues (HRHRHRHR) was synthesized by Fmoc/tBu solid-phase peptide synthesis. H-Arg(Pbf)-2-chlorotrityl resin $(0.3 \mathrm{mmol}, 732 \mathrm{mg}, 0.41 \mathrm{mmol} / \mathrm{g})$ was swelled in DMF and Fmoc groups were deprotected using $20 \%$ piperidine/DMF under nitrogen for two times $(20 \mathrm{~min} \times 2)$. Fmoc-His(Trt)-OH (557.74 mg, $0.9 \mathrm{mmol}$ ) and Fmoc-Arg(Pbf)-OH (583.89 mg, $0.9 \mathrm{mmol}$ ) were coupled alternatively to $\mathrm{NH}_{2}$ - $\mathrm{Arg}(\mathrm{Pbf})$-2-chlorotrityl resin in the presence of HBTU (341.32. $\mathrm{mg}, 0.9 \mathrm{mmol}$ ) and DIPEA ( $315 \mu \mathrm{L}, 1.8 \mathrm{mmol}$ ) in DMF. Coupling and deprotection cycles were repeated to assemble the sequence of the linear protected peptide. Then, the side-chain deprotection and cleavage from the resin were carried out by a cleavage cocktail reagent " $\mathrm{R}$ " (TFA/thioanisole/anisole/1,2-ethanedithiol (EDT), 90:5:2:3, v:v:v:v, $15 \mathrm{~mL}$ ) for $5 \mathrm{~h}$. The crude peptide was precipitated by the addition of cold diethyl ether $\left(75 \mathrm{~mL}, \mathrm{Et}_{2} \mathrm{O}\right)$ and purified by reversed-phase Hitachi HPLC (L-2455) on a water X Bridge TM BEH130 Prep C18 OBD $10 \mu \mathrm{m}$ ODS reversed-phase column $(2.1 \mathrm{~cm} \times 25 \mathrm{~cm})$ using a gradient system. The crude peptide was purified at a flow rate of $10.0 \mathrm{~mL} / \mathrm{min}$ using a gradient of $0-100 \%$ acetonitrile ( $0.1 \%$ TFA) and water (0.1\%TFA) over $60 \mathrm{~min}$ on RP-HPLC and then was lyophilized to obtain the linear peptide. 1(HR) $)_{4}$ : MALDI-TOF $(m / z): \mathrm{C}_{48} \mathrm{H}_{78} \mathrm{~N}_{28} \mathrm{O}_{9}$, calcd. 1190.6507; found $1191.5143[\mathrm{M}]^{+}$. Similarly, $1(\mathrm{HR})_{5}$ was synthesized. $1(\mathrm{HR})_{5}$ : MALDI-TOF $(m / z): \mathrm{C}_{60} \mathrm{H}_{97} \mathrm{~N}_{35} \mathrm{O}_{11}$; calcd. 1483.8107; found $1484.7310[\mathrm{M}+\mathrm{H}]^{+}$.

\subsubsection{Synthesis of Cyclic $[\mathrm{HR}]_{4}$ Peptide}

The linear peptide was assembled on $\mathrm{H}-\mathrm{Arg}(\mathrm{Pbf})-2$-chlorotrityl resin $(0.3 \mathrm{mmol}, 732 \mathrm{mg}$, $0.41 \mathrm{~mol} / \mathrm{g}$ ) after swelling in DMF for $30 \mathrm{~min}$ under nitrogen. Fmoc-His(Boc)-OH (473.9 mg, $0.9 \mathrm{mmol}$ ) and Fmoc-Arg(Pbf)-OH (583.9 mg, $0.9 \mathrm{mmol})$ were coupled alternatively as described above to synthesize linear peptide assembled on the resin. The side chain protected peptide was cleaved from the resin by shaking the resin with a mixture of trifluoroethanol (TFE)/acetic acid/dichloromethane (DCM) $(2: 2: 6, v / v / v, 50 \mathrm{~mL})$ for $2 \mathrm{~h}$. The resin was filtered off and the solution was evaporated to dryness under reduced pressure to yield side-chain protected linear peptide. Then cyclization of the linear peptide was carried out in the presence of DIC $(140 \mu \mathrm{L}, 0.9 \mathrm{mmol})$ and HOAt $(122.5 \mathrm{mg}, 0.9 \mathrm{mmol})$ in dry DMF/DCM $(200 \mathrm{~mL}, 3: 1 \mathrm{v} / \mathrm{v})$ under nitrogen stirring for $12 \mathrm{~h}$. After cyclization, the solvent was evaporated and the side chain deprotection was performed by addition of TFA/thioanisole/anisole/EDT (90:5:2:3, v:v:v:v, $15 \mathrm{~mL}$ ) and shaking on a shaker for $5 \mathrm{~h}$. The crude peptide was precipitated by the addition of cold diethyl ether $\left(75 \mathrm{~mL}, \mathrm{Et}_{2} \mathrm{O}\right)$ and purified by reversed-phase Hitachi HPLC (L-2455) on a Waters XBridgeTM BEH130 Prep C18 OBDTM $10 \mu \mathrm{m}$ ODS reversed-phase column $(2.1 \mathrm{~cm} \times 25 \mathrm{~cm})$ using a gradient system. The crude peptide was purified at a flow rate of $10.0 \mathrm{~mL} / \mathrm{min}$ using a gradient of $0-100 \%$ acetonitrile $(0.1 \%$ TFA) and water $(0.1 \%$ TFA) over $60 \mathrm{~min}$ and then was lyophilized to yield the pure cyclic peptide c[HR $]_{4}$ : MALDI-TOF $(m / z)$ for $\mathrm{C}_{48} \mathrm{H}_{76} \mathrm{~N}_{28} \mathrm{O}_{8}$, calcd. 1172.6401; found 1173.6167, $[\mathrm{M}+\mathrm{H}]^{+}$. Similarly, $\mathrm{c}[\mathrm{HR}]_{5}$ was synthesized. c $[\mathrm{HR}]_{5}:$ MALDI-TOF $(m / z): \mathrm{C}_{60} \mathrm{H}_{95} \mathrm{~N}_{35} \mathrm{O}_{10}$; calcd. 1465.8001; found $1466.8918[\mathrm{M}+\mathrm{H}]^{+}$.

\subsubsection{Synthesis of Lauryl-(HR $)_{4}$ Peptide}

The synthesis of fatty acyl derivatives of linear $(\mathrm{HR})_{4}$ peptides were carried on solid-phase. The peptide was synthesized using Fmoc-Arg(Pbf)-Wang resin $(0.3 \mathrm{mmol}, 750.0 \mathrm{mg}, 0.40 \mathrm{mmol} / \mathrm{g})$. Once, the linear peptide was assembled after coupling Fmoc-His(Trt)-OH (557.74 mg, $0.9 \mathrm{mmol})$ and Fmoc-Arg(Pbf)-OH (583.90 mg, $0.9 \mathrm{mmol}$ ) alternatively using HBTU (341.32. $\mathrm{mg}, 0.9 \mathrm{mmol}$ ) and DIPEA ( $315 \mu \mathrm{L}, 1.8 \mathrm{mmol})$ in DMF for $1 \mathrm{~h}$ with Fmoc deprotection in between each coupling cycle using 20\% piperidine in DMF. After the last coupling was completed, the resin was washed with DMF $(3 \times 15 \mathrm{~mL})$ followed by $N$-terminal Fmoc deprotection using $20 \%$ piperidine in DMF $(2 \times 10 \mathrm{~mL}$, $10 \mathrm{~min}$ each). Then, lauric acid $(180 \mathrm{mg}, 0.9 \mathrm{mmol})$ was coupled to the $N$-terminal of the linear $(\mathrm{HR})_{4}$ peptide using HBTU (341.32. $\mathrm{mg}, 0.9 \mathrm{mmol})$ and DIPEA $(315 \mu \mathrm{L}, 1.8 \mathrm{mmol})$ in the DMF. The resin 
was washed with DCM $(3 \times 25 \mathrm{~mL})$ and methanol $(3 \times 25 \mathrm{~mL})$ and vacuum dried. Then the resin and the side chain protecting groups were cleaved from the peptidyl resin using cleavage cocktail TFA/thioanisole/EDT/anisole (90:5:3:2, v:v:v:v, $15 \mathrm{~mL}$ ) for $5 \mathrm{~h}$. The crude peptide was precipitated by adding cold diethyl ether $\left(100 \mathrm{~mL}, \mathrm{Et}_{2} \mathrm{O}\right)$ and centrifuged at $4000 \mathrm{rpm}$ for $10 \mathrm{~min}$, followed by decantation to obtain the solid precipitate. The solid material was further washed with cold ether $(2 \times 100 \mathrm{~mL})$ for 2 times. The peptide was resolubilized in a solvent $\left(\mathrm{CH}_{3} \mathrm{CN}+0.1 \%\right.$ TFA and water $+0.1 \%$ TFA). The crude peptide was purified by using the reverse-phase high performance liquid chromatography (RP-HPLC) equipped with a Waters XBridgeTM BEH130 Prep C18 column OBDTM $10 \mu \mathrm{m}(19 \mathrm{~mm} \times 250 \mathrm{~mm})$. A gradient of $0-100 \%$ acetonitrile and water in $0.1 \%$ TFA $(v / v)$ with a flow rate at $10.0 \mathrm{~mL} / \mathrm{min}$ was used for the purification. The peptide powder was obtained after lyophilization of pure HPLC fraction. Other fatty acid conjugates of $(\mathrm{HR})_{4}$ were synthesized in a similar manner:

$\mathrm{CH}_{3} \mathrm{CO}-(\mathrm{HR})_{4}$ : MALDI-TOF $(\mathrm{m} / \mathrm{z}): \mathrm{C}_{50} \mathrm{H}_{80} \mathrm{~N}_{28} \mathrm{O}_{10}$; calcd, 1232.6612; found $1233.5829[\mathrm{M}+\mathrm{H}]^{+}$; $\mathrm{COOH}-\left(\mathrm{CH}_{2}\right)_{6}-\mathrm{CO}-(\mathrm{HR})_{4}$ : MALDI-TOF $(\mathrm{m} / \mathrm{z}): \mathrm{C}_{56} \mathrm{H}_{90} \mathrm{~N}_{28} \mathrm{O}_{12}$; calcd, 1346.7293; found 1347.5835 $[\mathrm{M}+\mathrm{H}]^{+} ; \mathrm{CH}_{3}-\left(\mathrm{CH}_{2}\right)_{10}-\mathrm{CO}-(\mathrm{HR})_{4}$ : MALDI-TOF $(\mathrm{m} / z): \mathrm{C}_{60} \mathrm{H}_{100} \mathrm{~N}_{28} \mathrm{O}_{10}$; calcd, 1372.8177; found $1373.8236[\mathrm{M}+\mathrm{H}]^{+} ; \mathrm{CH}_{3}-\left(\mathrm{CH}_{2}\right)_{12}-\mathrm{CO}-(\mathrm{HR})_{4}$ : MALDI-TOF $(\mathrm{m} / z): \mathrm{C}_{62} \mathrm{H}_{104} \mathrm{~N}_{28} \mathrm{O}_{10} ;$ calcd, 1400.8490 found $1401.6533[\mathrm{M}+\mathrm{H}]^{+} ; \mathrm{CH}_{3}-\left(\mathrm{CH}_{2}\right)_{14}-\mathrm{CO}-(\mathrm{HR})_{4}:$ MALDI-TOF $(\mathrm{m} / z): \mathrm{C}_{64} \mathrm{H}_{108} \mathrm{~N}_{28} \mathrm{O}_{10}$; calcd, 1428.8803; found $1429.9110[\mathrm{M}+\mathrm{H}]^{+} ; \mathrm{CH}_{3}-\left(\mathrm{CH}_{2}\right)_{7} \mathrm{CH}=\mathrm{CH}\left(\mathrm{CH}_{2}\right)_{7}-\mathrm{CO}-(\mathrm{HR})_{4}$ : MALDI-TOF $(m / z): \quad \mathrm{C}_{66} \mathrm{H}_{109} \mathrm{~N}_{28} \mathrm{O}_{10}$; calcd, 1454.8960; found $1455.6722[\mathrm{M}+\mathrm{H}]^{+} ; \mathrm{CH}_{3}-\left(\mathrm{CH}_{2}\right)_{18}-\mathrm{CO}-(\mathrm{HR})_{4}$ : MALDI-TOF $(m / z): \quad \mathrm{C}_{68} \mathrm{H}_{111} \mathrm{~N}_{28} \mathrm{O}_{10} ; \quad$ calcd, $1484.9429 ;$ found $1485.7854[\mathrm{M}+\mathrm{H}]^{+}$; $\mathrm{CH}_{3}-\left(\mathrm{CH}_{2}\right)_{18}-\mathrm{CO}-(\mathrm{HR})_{5}$ : MALDI-TOF $(\mathrm{m} / z): \mathrm{C}_{80} \mathrm{H}_{135} \mathrm{~N}_{35} \mathrm{O}_{12}$; calcd, 1778.1029; found 1778.8019 $[\mathrm{M}]^{+} ; \mathrm{CH}_{3}-\left(\mathrm{CH}_{2}\right)_{18}-\mathrm{CO}-(\mathrm{HR})_{3}$ : MALDI-TOF $(\mathrm{m} / \mathrm{z}): \mathrm{C}_{56} \mathrm{H}_{79} \mathrm{~N}_{21} \mathrm{O}_{8}$; calcd, 1191.7829; found, 1192.7028 $[\mathrm{M}+\mathrm{H}]^{+} ; \mathrm{CH}_{3}-\left(\mathrm{CH}_{2}\right)_{18}-\mathrm{CO}-(\mathrm{HR})_{2}:$ MALDI-TOF $(m / z): \mathrm{C}_{62} \mathrm{H}_{104} \mathrm{~N}_{28} \mathrm{O}_{10} ;$ calcd, 898.6229 found, 899.3463; [M+ H] $]^{+}$.

\subsection{Cell Culture}

Human leukemia CCRF-CEM (ATCC no. CCL-119) and ovarian carcinoma SK-OV-3 (ATCC no. HTB-77) cell lines were obtained from American Type Culture Collection. Cells were grown on $75 \mathrm{~cm}^{2}$ cell culture flasks with Roswell Park Memorial Institute (RPMI)-1640 medium (for CCRF-CEM) and Eagle's minimum essential medium (EMEM) (for SK-OV-3), supplemented with 10\% fetal bovine serum (FBS) and 1\% penicillin-streptomycin solution (10,000 units of penicillin and $10 \mathrm{mg}$ of streptomycin in $0.9 \% \mathrm{NaCl}$ ) in a humidified atmosphere of $5 \% \mathrm{CO}_{2}, 95 \%$ air at $37^{\circ} \mathrm{C}$. All bioassays were performed in triplicate.

\subsection{Cell Viability Assays Using MTT}

The cytotoxicity assay was performed via an MTS proliferation assay in CCRF-CEM and SK-OV-3 cells. 5000 cells were incubated with $100 \mu \mathrm{L}$ of complete media and allowed to grow for overnight in each well of the 96 well plates. The linear and cyclic peptides at concentrations (5, 10, 25, 50 and $100 \mu \mathrm{M}$ ) were added to the cells and incubated at $37^{\circ} \mathrm{C}$ with $5 \%$ carbon dioxide for $72 \mathrm{~h}$. After $72 \mathrm{~h}$ of incubation, the $\mathrm{pH}$ of media were tested. Both cell lines with/without $(\mathrm{HR})_{4}$ treatment were found to be acidic $(\sim 6.5)$ whereas the cells treated with $\mathrm{C}_{20}-(\mathrm{HR})_{4}$ were slightly basic $(\mathrm{pH} \sim 7.5)$. Then $20 \mu \mathrm{L}$ of MTS reagent was added to each well. CCRF-CEM cells were incubated for $3 \mathrm{~h}$, and SK-OV-3 cells were incubated for $1 \mathrm{~h}$ at $37^{\circ} \mathrm{C}$ with $5 \%$ carbon dioxide. The fluorescence intensity of the formazan product was measured at $490 \mathrm{~nm}$ using a Spectra Max M2 microplate spectrophotometer. The percentage of cell survival was calculated as [(OD value of cells treated with the test mixture of compounds) (OD value of culture medium) $] /[(\mathrm{OD}$ value of control cells $)-($ OD value of culture medium) $] \times 100 \%$. 


\subsection{Cellular Uptake Studies of Fluorescein-Labeled Phosphopeptide by Flow Cytometry}

The cellular uptake assays were performed via FACS analysis using SK-OV-3 and CCRF-CEM cells in 6-well plates. The fluorescein-labeled phosphopeptide ( $\mathrm{F}^{\prime}$-GpYEEI) was added to the well plates at a concentration of $5 \mu \mathrm{M}$, and the peptides were added to the well in each plate at a concentration of 5,10 and $50 \mu \mathrm{M}$. The cells were incubated at $37^{\circ} \mathrm{C}$ with $5 \%$ carbon dioxide for $2 \mathrm{~h}$. The cells were digested with $0.25 \%$ trypsin, $0.53 \mathrm{mM}$ EDTA for $5 \mathrm{~min}$ to detach from the surface followed by addition of $2 \mathrm{~mL}$ of complete media to deactivate the trypsin. The cells were centrifuged at $2500 \mathrm{rpm}$ and washed with PBS for two times. Finally, the cells were resuspended in $400 \mu \mathrm{L}$ of flow cytometry buffer and analyzed by flow cytometry. The data presented are based on the mean fluorescence signal for 10,000 cells collected. All assays were performed in triplicate.

\subsection{Antiproliferative Assay of the Anticancer Drugs Using $\mathrm{C}_{20}-(\mathrm{HR})_{4}$}

The antiproliferative assay was performed using MTT proliferation assay in CCRF-CEM and SK-OV-3 cells. The cells were incubated with $100 \mu \mathrm{L}$ of complete media overnight in a 96 well plate. The anticancer drugs namely (Doxorubicin, Etoposide, Cis-platin, Epirubicin, Paclitaxel, and Gemcitabine) were added to the well plates at a concentration of $5 \mu \mathrm{M}$ and $\mathrm{C}_{20}-(\mathrm{HR})_{4}$ was added to the cells at a concentration of $50 \mu \mathrm{M}$. The cells were incubated at $37^{\circ} \mathrm{C}$ with $5 \% \mathrm{CO}_{2}$ for $72 \mathrm{~h}$. Then $20 \mu \mathrm{L}$ of MTT was added to each well. After addition of MTT reagent, CCRF-CEM cells were incubated for $3 \mathrm{~h}$ and SK-OV-3 cells were incubated for $1 \mathrm{~h}$ at $37^{\circ} \mathrm{C}$ with $5 \% \mathrm{CO}_{2}$. The absorbance (and thus percent cell viability) was obtained at a wavelength of $490 \mathrm{~nm}$ using a microplate reader.

\section{Conclusions}

In conclusion, a new series of linear and cyclic homochiral amphipathic peptides, which consists of alternating arginine and histidine amino acids, were synthesized. Both linear and cyclic peptides showed $0-13 \%$ cytotoxicity on SK-OV-3 and CCRF-CEM. Among the investigated peptides, $c[\mathrm{HR}]_{4}$ proved to be promising as molecular transporters for $\mathrm{F}^{\prime}$-GpYEEI phosphopeptide. The attachment of different fatty acids to $1(\mathrm{HR})_{4}$ peptide modulated its toxicity profile and molecular transporter property. $\mathrm{C}_{2^{-}}, \mathrm{C}_{8^{-}}, \mathrm{C}_{12^{-}}, \mathrm{C}_{14^{-}}, \mathrm{C}_{18^{-}}(\mathrm{HR})_{4}$ were not toxic up to $50 \mu \mathrm{M}$ concentration while $\mathrm{C}_{16^{-}}(\mathrm{HR})_{4}$ and $\mathrm{C}_{20^{-}}(\mathrm{HR})_{4}$ exhibited a significant reduction in the cell viability at the same concentration. Our studies revealed that the cellular uptake of $\mathrm{F}^{\prime}$-GpYEEI phosphopeptide by $\mathrm{C}_{20}-(\mathrm{HR})_{4}$ was significantly improved and was concentration dependent. Increasing the number of amino acids increased the efficacy of the $\mathrm{C}_{20}-[\mathrm{HR}]_{\mathrm{n}}$ peptide in translocating $\mathrm{F}^{\prime}$-GPYEEI phosphopeptide into the cells. When $\mathrm{C}_{20}-(\mathrm{HR})_{4}$ mixed with several anticancer drugs, the antiproliferation potency of doxorubicin and epirubicin increased more than the parent alone in SK-OV-3 cell line.

Supplementary Materials: The supplementary materials are available online containing MALDI-MS spectra of synthesized peptides.

Author Contributions: R.T. and K.P. planned and designed the experiments; N.S.E.-S., T.M., J.C., S.B., A.N.S., and S.E.P. synthesized peptides and performed the cell assay; N.S.E.-S., T.M., J.C., S.B. and A.N.S., analyzed the data; K.P. and R.T. contributed reagents/materials/analysis tools; N.S.E.-S., K.P. and R.T. wrote the paper.

Funding: This research was funded by Chapman University School of Pharmacy.

Acknowledgments: The authors greatly acknowledge financial support for this research from Chapman University School of Pharmacy.

Conflicts of Interest: The authors declare no conflict of interest.

\section{References}

1. Deshayes, S.; Morris, M.C.; Divita, G.; Heitz, F. Cell-penetrating peptides: Tools for intracellular delivery of therapeutics. Cell Mol. Life Sci. 2005, 62, 1839-1849. [CrossRef] [PubMed]

2. Mandal, D.; Nasrolahi Shirazi, A.; Parang, K. Cell-Penetrating Homochiral Cyclic Peptides as Nuclear-Targeting Molecular Transporters. Angew. Chem. Int. Ed. 2011, 50, 9633-9637. [CrossRef] [PubMed] 
3. Mäe, M.; Langel, Ü. Cell-penetrating peptides as vectors for peptide, protein and oligonucleotide delivery. Curr. Opin. Pharmacol. 2006, 6, 509-514. [CrossRef] [PubMed]

4. Stewart, K.M.; Horton, K.L.; Kelley, S.O. Cell-penetrating peptides as delivery vehicles for biology and medicine. Org. Biomol. Chem. 2008, 6, 2242-2255. [CrossRef] [PubMed]

5. Fonseca, S.B.; Pereira, M.P.; Kelley, S.O. Recent advances in the use of cell-penetrating peptides for medical and biological applications. Adv. Drug Deliv. Rev. 2009, 61, 953-964. [CrossRef] [PubMed]

6. Olson, E.S.; Jiang, T.; Aguilera, T.A.; Nguyen, Q.T.; Ellies, L.G.; Scadeng, M.; Tsien, R.Y. Activatable cell penetrating peptides linked to nanoparticles as dual probes for in vivo fluorescence and MR imaging of proteases. Proc. Natl. Acad. Sci. USA 2010, 107, 4311-4316. [CrossRef] [PubMed]

7. Wagstff, K.M.; Jans, D.A. Protein transduction: Cell penetrating peptides and their therapeutic applications. Curr. Med. Chem. 2006, 13, 1371-1387. [CrossRef]

8. Milletti, F. Cell-penetrating peptides: Classes, origin and current landscape. Drug Discov. Today 2012, 17, 850-860. [CrossRef] [PubMed]

9. Zorko, M.; Langel, Ü. Cell-penetrating peptides: Mechanism and kinetics of cargo delivery. Adv. Drug Deliv. Rev. 2005, 57, 529-545. [CrossRef] [PubMed]

10. Madani, F.; Abdo, R.; Lindberg, S.; Hirose, H.; Futaki, S.; Langel, Ü.; Gräslund, A. Modeling the endosomal escape of cell-penetrating peptides using a transmembrane $\mathrm{pH}$ gradient. Biochim. Biophys. Acta 2013, 1828, 1198-1204. [CrossRef] [PubMed]

11. Reissmann, S. Cell penetration: Scope and limitations by the application of cell-penetrating peptides. J. Pept. Sci. 2014, 20, 760-784. [CrossRef] [PubMed]

12. Cairns, R.; Papandreou, I.; Denko, N. Overcoming physiologic barriers to cancer treatment by molecularly targeting the tumor microenvironment. Mol. Cancer Res. 2006, 4, 61-70. [CrossRef] [PubMed]

13. Semenza, G.L. Defining the role of hypoxia-inducible factor 1 in cancer biology and therapeutics. Oncogene 2010, 29, 625-634. [CrossRef] [PubMed]

14. Murphy, E.A.; Majeti, B.K.; Barnes, L.A.; Makale, M.; Weis, S.M.; Lutu-Fuga, K.; Wrasidlo, W.; Cheresh, D.A. Nanoparticle-mediated drug delivery to tumor vasculature suppresses metastasis. Proc. Natl. Acad. Sci. USA 2008, 105, 9343-9348. [CrossRef] [PubMed]

15. Torchilin, V.P. Targeted pharmaceutical nanocarriers for cancer therapy and imaging. AAPS J. 2007, 9 , E128-E147. [CrossRef] [PubMed]

16. Gaspar, V.M.; Cruz, C.; Queiroz, J.A.; Pichon, C.; Correia, I.J.; Sousa, F. Highly selective capture of minicircle DNA biopharmaceuticals by a novel zinc-histidine peptide conjugate. Sep. Purif. Technol. 2017, 174, 417-424. [CrossRef]

17. Liu, B.R.; Huang, Y.W.; Winiarz, J.G.; Chiang, H.J.; Lee, H.J. Intracellular delivery of quantum dots mediated by a histidine-and arginine-rich HR9 cell-penetrating peptide through the direct membrane translocation mechanism. Biomaterials 2011, 32, 3520-3537. [CrossRef] [PubMed]

18. Li, H.; Luo, T.; Sheng, R.; Sung, J.; Wang, Z.; Cao, A. Achieving high gene delivery performance with caveolae-mediated endocytosis pathway by (l)-arginine/(l)-histidine co-modified cationic gene carriers. Coll. Surf. B Biointerf. 2016, 148, 73-84. [CrossRef] [PubMed]

19. Bacalum, M.; Janosi, L.; Zorila, F.; Tepes, A.M.; Ionescu, C.; Bogdan, E.; Hadade, N.; Craciun, L.; Grosu, I.; Turcu, I.; et al. Modulating short tryptophan-and arginine-rich peptides activity by substitution with histidine. Biochim. Biophys. Acta 2017, 1861, 1844-1854. [CrossRef] [PubMed]

20. Mandal, D.; Shirazi, A.N.; Parang, K. Self-assembly of peptides to nanostructures. Org. Biomol. Chem. 2014, 12, 3544-3561. [CrossRef] [PubMed]

21. Shirazi, A.N.; Tiwari, R.K.; Chhikara, B.S.; Mandal, D.; Parang, K. Design and biological evaluation of cell-penetrating peptide-doxorubicin conjugates as prodrugs. Mol. Pharm. 2013, 10, 488-499. [CrossRef] [PubMed]

22. Shirazi, A.N.; Tiwari, R.K.; Oh, D.; Banerjee, A.; Yadav, A.; Parang, K. Efficient delivery of cell impermeable phosphopeptides by a cyclic peptide amphiphile containing tryptophan and arginine. Mol. Pharm. 2013, 10, 2008-2020. [CrossRef] [PubMed]

23. Shirazi, A.N.; Paquin, K.L.; Howlett, N.G.; Mandal, D.; Parang, K. Cyclic peptide-capped gold nanoparticles for enhanced siRNA delivery. Molecules 2014, 19, 13319-13331. [CrossRef] [PubMed] 
24. Shirazi, A.N.; El-Sayed, N.S.; Tiwari, R.K.; Tavakoli, K.; Parang, K. Cyclic peptide containing hydrophobic and positively charged residues as a drug delivery system for curcumin. Curr. Drug Deliv. 2016, 13, 409-417. [CrossRef] [PubMed]

25. Shirazi, A.N.; El-Sayed, N.S.; Mandal, D.; Tiwari, R.K.; Tavakoli, K.; Etesham, M.; Parang, K. Cysteine and arginine-rich peptides as molecular carriers. Bioorg. Med. Chem. Lett. 2016, 26, 656-661. [CrossRef] [PubMed]

26. Lee, E.S.; Shin, H.J.; Na, K.; Bae, Y.H. Poly(l-histidine)-PEG block copolymer micelles and pH-induced destabilization. J. Cont. Release 2003, 90, 363-374. [CrossRef]

27. Sharma, M.; El-Sayed, N.S.; Do, H.; Parang, K.; Tiwari, R.K.; Aliabadi, H.M. Tumor-targeted delivery of siRNA using fatty acyl-CGKRK peptide conjugates. Sci. Rep. 2017, 7, 6093. [CrossRef] [PubMed]

28. Mäe, M.; Andaloussi, S.E.; Lundin, P.; Oskolkov, N.; Johansson, H.J.; Guterstam, P.; Langel, Ü.A. Stearylated CPP for delivery of splice correcting oligonucleotides using a non-covalent co-incubation strategy. J. Control Release 2009, 134, 221-227. [CrossRef] [PubMed]

29. Katayama, S.; Hirose, H.; Takayama, K.; Nakase, I.; Futaki, S. Acylation of octaarginine: Implication to the use of intracellular delivery vectors. J. Control Release. 2011, 149, 29-35. [CrossRef] [PubMed]

30. Yaffe, M.B. Phosphotyrosine-binding domains in signal transduction. Nat. Rev. Mol. Cell Biol. 2002, 3, 177-186. [CrossRef] [PubMed]

Sample Availability: Samples of the compounds are available from the authors for a short period of time. 